\title{
DESCRIPTION OF A DOUBLE SLIDE EXPANSION VALVE FOR MARINE ENGINES.
}

The writer, feeling convinced of the necessity of using expansion valves for the engines of screw steamers, applied the valves described in the present paper to the engines of the serew ship "Lord Raglan," one of the Tyne and Continental Steam Navigation Company's vessels, built on the Clyde.

The objects sought to be obtained by the application of these valves are, first, to afford a facility for using the full power of the engines when necessary for any length of time, the boilers being made large enough to supply a sufficient quantity of steam, even when cleaning the fires, and to allow of the necessary amount of blowing off at sea. Secondly, to provide an efficient expansion valve for reducing the power of the engines to any limit required, so as to gain an increased advantage in the results obtained from the consumption of a given quantity of fuel, compared with that which could be gained by the ordinary practice of wiredrawing the steam by the regulator valve. Thirdly, to provide the means of altering the degree of expansion, without at the same time altering the lead of the valve, or the time of exhausting from the cylinder into the condenser. 
The valves are shown in Figs. 1 and 2, Plate 52; they are a modifcation of Messrs. Hawthorn's expansion valves for locomotive engines. The slide valve $A$ of each engine is worked by a pair of eccentrics $B B$ connected by a link $\mathrm{C}$ for reversing the motion in the ordinary way. A cutoff slide $D$ is placed on the back of the slide valve $A$, through which the steam has to pass, and this is worked by a third eccentric $\mathrm{E}$ through an expansion link F. The lower end of the link $\mathrm{F}$ is connected to a concentric ring $G$ on the axle, and is consequently stationary, so that by sliding the rod of the cut-off slide D to the lower end of the link its motion is stopped, and the valve remains full open throughout the stroke, the engines then working at their full power. The expansion link $\mathrm{F}$ can be adjusted by the lever $\mathrm{H}$ to cut off the steam at any point required in forward gear, and the combired action of the two slides gives a more prompt cutting off with less wiredrawing of the steam than in the case of the ordinary single slide valve. In backward gear the ordinary slide $\mathrm{A}$ alone is required to act, the reversing being effected by the lever I; the link $\mathrm{C}$ is used only for reversing, and can be fixed only in the extreme positions of forward and backward gear, the expansion being regulated by the cut-off slide $\mathrm{D}$ alone.

In the engines shown in the figures, the pistons have 30 inches stroke, and the main valves $A$ are set to cut off at $22 \frac{1}{2}$ inches or $\frac{3}{4}$ th from the commencement of the stroke. By moving the link $F$ to any point between the centres of the two rods $E$ and $G$, and thereby varying the length of travel of the expansion valve $D$, the steam may be cut off at any point between $\frac{3}{4}$ ths of the stroke, when the rod $G$ is in full gear and the engines are working at their full power, and $\frac{1}{4}$ th of the stroke, when the rod $E$ is in full gear and the expansion is carried out to the maximum degree.

This arrangement of valves has been in constant use on board the screw steamer "Lord Raglan" for the last nine months, during which time the vessel has run 14,000 miles, and the valves have given every satisfaction as to their efficiency, by the economy of fuel attending the use of them, and by their non-liability to derangement, and the ease with which their working can be regulated at any time according to the situation in which the ship may be placed, so as either to employ the full power of the engines, or to economize fuel for a long voyage by working expansively.

The following Table shows the results obtained from experiments at sea, including loss by blowing off necessary to keep the boilers clean, cleaning of fires, \&c., incidental to steam navigation. 
Consumption of Fuel of the "Lord Raglan" Screw Steamer, with the Double Slide Expansion Valve.

\begin{tabular}{|c|c|c|c|c|c|c|c|}
\hline $\begin{array}{c}\text { Expansion } \\
\text { in per- } \\
\text { centage of } \\
\text { Stroke. }\end{array}$ & $\begin{array}{c}\text { Number } \\
\text { of } \\
\text { Strokes } \\
\text { perminute. }\end{array}$ & $\begin{array}{c}\text { Comparative } \\
\text { Speed } \\
\text { of } \\
\text { ship. }\end{array}$ & $\begin{array}{c}\text { Loss of } \\
\text { speed } \\
\text { of } \\
\text { ship. }\end{array}$ & $\begin{array}{c}\text { Consump- } \\
\text { tion of } \\
\text { Coai } \\
\text { per hour. }\end{array}$ & $\mid \begin{array}{c}\text { Per-Centage } \\
\text { Consumption } \\
\text { of } \\
\text { Coal. }\end{array}$ & $\begin{array}{c}\text { Per-Cent- } \\
\text { age Saving } \\
\text { of } \\
\text { Coal. }\end{array}$ & $\begin{array}{l}\text { Per-Centage } \\
\text { Gain of Dis- } \\
\text { tance rum by } \\
\text { same con- } \\
\text { sumption of } \\
\text { Coal. } \\
\end{array}$ \\
\hline Per Cent. & & & & Cwts. & Per Cent. & Per Cent. & Per Cent. \\
\hline 25 & 75 & 100 & 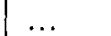 & 18 & 100 & & ... \\
\hline 33 & 75 nearly & 100 nearly & 0 nearly & 18 nearly & 100 nearly & 0 nearly & 0 nearly \\
\hline 45 & 72 & 96 & 4 & 16 & 86 & 11 & $7 \frac{1}{8}$ \\
\hline 50 & 69 & 92 & 8 & 13 & 72 & 28 & 22 \\
\hline 58 & $67 \frac{1}{2}$ & 90 & 10 & 10 & 59 & 44 & 38 \\
\hline
\end{tabular}

The description of coals used in the above trials was West Hartley.

In consequence of the absence of the vessel in the Crimea, the writer has not been enabled to give the general results up to the present time, as he had expected to do.

Mr. WyMER exhibited a model of the double slide valve, and showed the action of the cut-off slide with various degrees of expansion.

The Charrman observed that the double slide valve reminded him of the valve invented by the late Mr. Bodmer, which had a cut-off slide acting in a similar manner, and had been tried in several kinds of engines, including locomotives.

Mr. Beyer had used Bodmer's double valves formerly in several locomotives, and had found them work well as long as they were kept in good repair, but they did not stand well, on account of the great rapidity of reciprocation; the single valve and link motion was preferable for locomotive engines. The double slide valves would no doubt answer better for stationary or marine engines, where the motion was slower, as in the arrangement described in the paper.

Mr. Fenton remarked that the addition of the cut-off slide gave a better means for adjusting the degree of expansion; he asked whether it had an advantage in facilitating the exhaust.

Mr. BEYER explained that the exhaust remained always the same, and opened to the full extent for all degrees of expansion, the admission alone 
being affected by the cut-off slide; and in this consisted the advantage of the double slide over the single valve.

Mr. MrLLer asked what metal was used for the valves and cylinder faces in the engines in which the trial of the new valves had been made.

Mr. WYMER replied that both of the valves were of cast iron, as well as the cylinder faces; they were not found to be worn after running 14,000 miles, but remained in a very good state; the ressel was at present abroad, and the valves had been examined in the week previous to her last sailing. He had at first used the ordinary link motion for marine engines, but had found a difficulty in preventing the engine from "knocking on the centres," in consequence of the increase of lead at high degrees of expansion, and the additional defect of variation in the exhaust that took place with the ordinary link motion; these circumstances affected large engines seriously, although they were not of importance in small quick-moving engines such as locomotives. By the use of the double slide valve that had been described the lead was kept the same and the exhaust remained constant for all degrees of expansion, the amount of expansion being regulated by the cut-off slide.

A vote of thanks was then passed to Mr. Wymer for his communication.

The following Paper, by Mr. Charles Beyer, of Manchester, was then read :- 
Fig.1.

Plon at back of Valves.
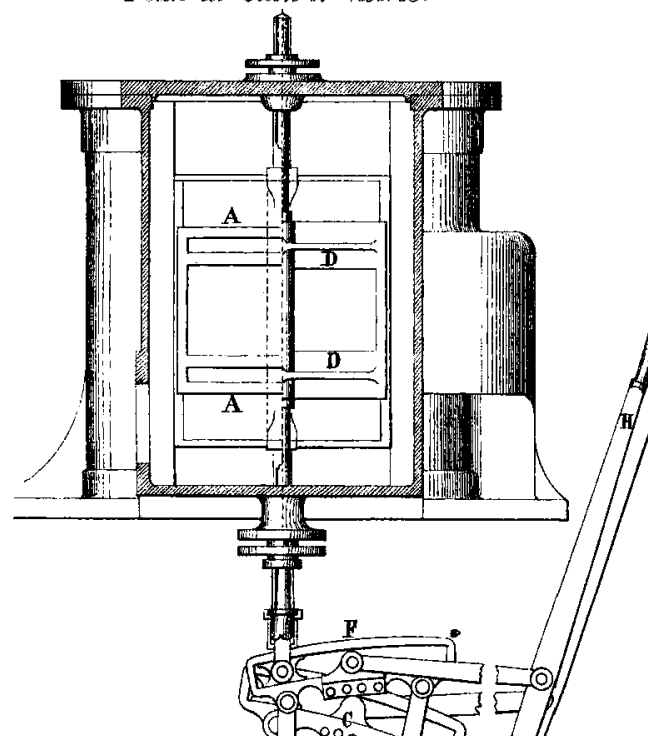

Pig. 2.

Section through Vatvers.
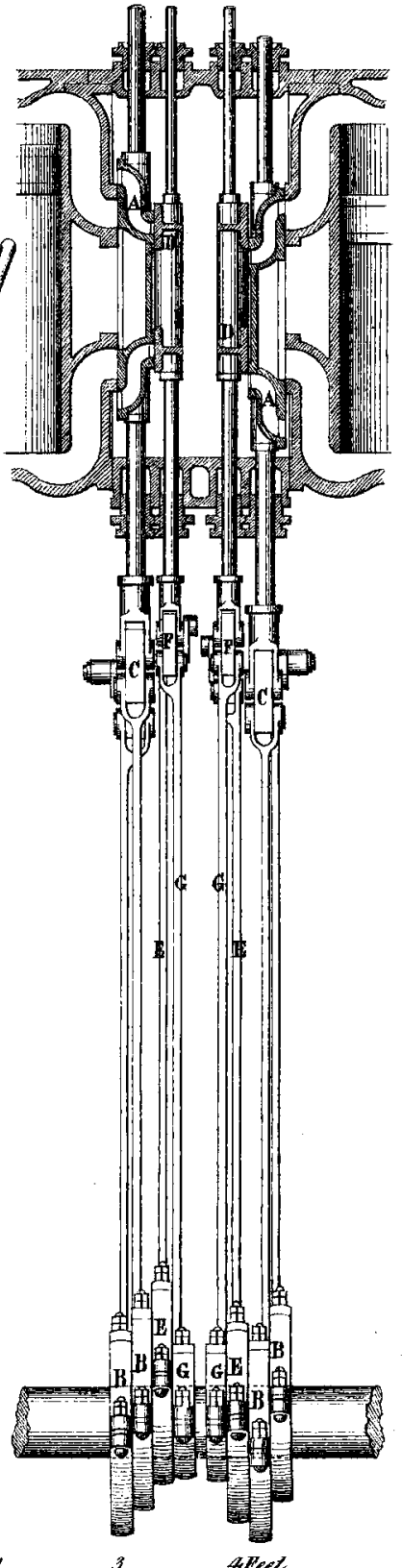

Scatetzath ins 72 of
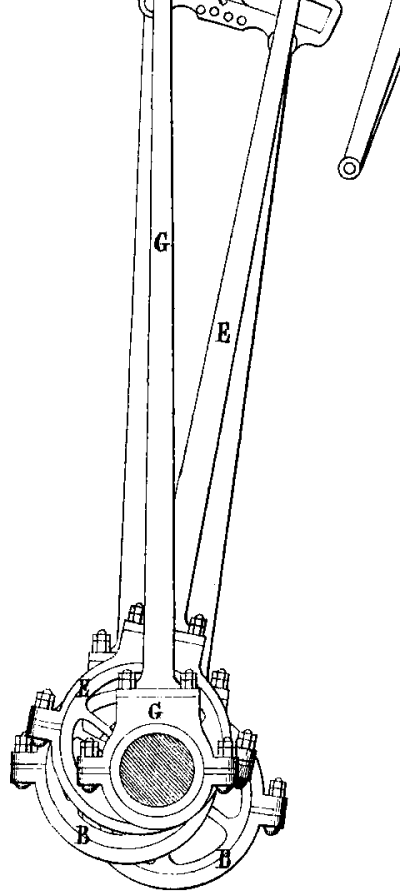

G

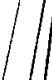

E

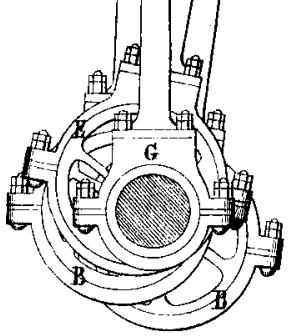

Alped.

(Proneedings Inolh. W.E. 1856. Page 59.)

Downloaded from pme.sagepub.com at WEST VIRGINA UNIV on June 5, 2016 